\title{
MONITORING AND TREATMENT OF ATRAZINE IN KAFR ELSHEIKH REGION WATER
}

\author{
Abd-Al Razek Taha M. ${ }^{(1)}$; Wahba, S. Z. ${ }^{(2)}$ and Moustafa, M. F. ${ }^{(3)}$ \\ 1) Institute of Environmental Studies \& Research, Ain Shams University. \\ 2) National Research Center, Egypt. 3) Holding Company for Water and \\ Wastewater, Cairo, Egypt.
}

\begin{abstract}
Pesticides have negative impact on the human health and environment. They were classified as possible human carcinogens. World health organization (WHO) has set a limit for Atrazine (ATZ) at concentration 2 ppb. This work aims to monitor Atrazine in drinking and related raw water of Kafr El Sheikh governorate. Different treatment techniques for Atrazine removal like Fenton reaction and granulated activated carbon (GAC). The identification and quantification of Atrazine was explored using LC/MS/MS spectrometer. The study recorded the presence of Atrazine during summer spring and autumn in drinking and related raw water due to using it as herbicides in corn crops and the highest influent of atrazine was $0.15 \mu \mathrm{g} / \mathrm{l}$. The study showed that water purification steps have no effect on Atrazine treatment. Some trials were carried out to degrades and adsorb Atrazine using Fenton reaction and GAC. $99 \%$ of Atrazine was removed after one hour by using Fenton oxidation, 97\% was removed after two hours by using (GAC).

Key Words: Atrazine, Adsorption, Fenton oxidation and Kinetics.
\end{abstract}




\section{INTRODUCTION}<smiles>CCNc1nc(Cl)nc(NC(C)C)n1</smiles>

Figure 1: Atrazine (2-chloro-4-(ethylamino)-6-(isopropylamino) - s-triazine)

Agrochemicals constitute one of the most important synthetic chemical families that are bio-resistant and continuously released to the environment as a result of their industrial use and agricultural applications. The majority of these compounds either in their parent form or in other forms resulting from their participation in various biotic or abiotic processes in the environment can exhibited dangerous behavior towards organisms including among disruption activity and mutagenicity. Pesticides, insecticides, acaricides, herbicides, etc., are found in the environment all over the world, and numerous studies have focused on the presence of such compounds in fresh water (Calver et al., 2006). (ATZ) with the chemical name 2-chloro-4(ethylamino)-6-(isopropylamino) - s-triazine $(\mathrm{C} 8 \mathrm{H} 14 \mathrm{CIN} 5, \mathrm{MCIET}=215,7$ $\mathrm{g} / \mathrm{mol}$ ) which it's solubility in water approximately $30 \mathrm{mg} / \mathrm{L}$ and half live in soil is 15-100 days (El Sebaï et al., 2011) and (Ralebitso et al., 2002). Atrazine Belongs to the s-triazine ring herbicides and therefore was characterized as bio-recalcitrant. Its potential environmental hazard for polluting drinking water has led some countries to ban this herbicide (Chan and Chu, 2003). (ATZ) is mainly intended to control broad leaf and some grassy weeds (Guan et al., 2013). For this reason it is extensively used in 54 
agricultural applications to corn and rice, but substantial use is also made in the case of sorghum and sugarcane. Moreover, ATZ is widely applied on nonagricultural sites such as lawns and turf. As far as the mode of action is concerned, ATZ blocks electron transport in chloroplast's photo system II complex, thereby preventing $\mathrm{CO}_{2}$ fixation and subsequent energy production. Plant death occurs mostly by desiccation following membrane damage, because of formation of reactive species $\left(\mathrm{O}_{2}\right.$ and triplet-state chlorophyll) that trigger a chain reaction of lipid per oxidation (Marchetti et al., 2013). From among triazine pesticides, atrazine and its metabolites, Diethylatrazine and Deisopropylatrazine, can still be found in drinking water supplies throughout the EU, due to their usage as maize and sugar beet pesticide. Chromosome damage to Chinese hamster egg cells were observed if they were exposed to $0.005-0.080 \mu \mathrm{mol} / \mathrm{L}$ of atrazine, within two days. Two well-known atrazine metabolites, deethylatrazine and deisopropylatrazine, were found to be potentially carcinogenic, therefore the admissible levels for each pesticide individually in water are set at $0.1 \mu \mathrm{g} / \mathrm{L}$, and the sum should not exceed 0.5 $\mu \mathrm{g} / \mathrm{L}$ in EU (Thurman et al., 1994). USEPA (US Environmental Protection Agency) set the total admissible levels for atrazine, deethylatrazine and deisopropylatrazine in groundwater at $3 \mu \mathrm{g} / \mathrm{L}$ (Richards et al., 1995). A study by USEPA in 2003 showed that triazines - atrazine, simazine and propazine as well as metabolites - deethylatrazine and deisopropylatrazine in deethyldeisopropylatrazine - have the same mechanism concerning endocrine disruptions. A numerated compounds act the same way on human bodies, therefore, USEPA introduced the sum of all chloro-s-triazines. They are 
slowly biodegradable microbiologically (Reid et al., 2003). ATZ removal from drinking water sources is impossible using chlorination, aeration, filtration or coagulation. Quite effective technologies include activated carbon, ozonation, membrane separation, and biofiltration. The most effective techniques for ATZ removal are reverse osmosis (RO) and Nano filtration (NF) membranes (Jiang and Adams, 2006). Pesticides can degrade in the environment through microbial decomposition, UV photolysis, chemical oxidation, or hydrolysis. Adsorption is well-established technique for the removal of low concentrations of organic pollutants from large volumes of potable water, process effluents, wastewater, and aqueous solutions. Adsorption onto activated carbon is often considered as the most economical and efficient process for the removal of organic compounds in dilutes aqueous solutions. Activated carbons are profusely used as adsorbents for decontamination processes because of their extended surface area, high adsorption capacity, microporous structure, and special surface reactivity (Hamdaoui et al., 2005). Advanced oxidation processes (AOP) are well known for generating highly reactive and non-selective hydroxyl radical species, which are used to degrade (and mineralize into water, carbon dioxide and mineral salts) most of organics present in water and wastewater. The Fenton process as an AOPs usually involves four stages: $\mathrm{pH}$ adjustment, oxidation, neutralization, and (coagulation and precipitation) (Benatti et al., 2006, Wadley and Waite (2004) and Bautista et al. (2007) Fenton process for wastewater treatment has many advantages compared with other AOPs., The Fenton reagents are easy-to-handle, inexpensive, abundant, non-toxic and 
environmentally benign in diluted form, and they possess oxidative and coagulative properties, no additional energy input required to activate $\mathrm{H}_{2} \mathrm{O}_{2}$ and no special equipment required.

Our work aims to monitor atrazine in raw and drinking water of Kafr El Sheikh Governorate and its treatability.

\section{2-MATERIALS \& METHODS}

\section{2-1 Monitoring of Atrazine in Kafr El Sheikh Governorate:}

A survey of pesticides was performed in raw water and produced treated water (drinking) of all water treatment plants in K. El Sheikh Governorate (18 plants).

a) Materials: Atrazine $99.9 \%$ purity was obtained from Accustandard. Hydrogen peroxide 33\% was purchased from Panreac. Ferrous sulfate, methanol (99.9\%) purity, sodium thiosulfate and sodium hydroxide from Sigma Aldrich. $\mathrm{HCl}(37 \%)$ purity from Fisher. Granulated activated carbon from Chemviron-grade (207EA $12.5 * 40$ US).

b) Instrument: LC MS/MS instrument from waters, $\mathrm{pH}$ meter from Hack

c) Methods: Samples were collected from water treatment plants were monitored and quantified for atrazine by (EPA 536, 2007) using LC/MS/MS. This method is applicable for the determination of atrazine in raw water, finished drinking water and drinking water during

intermediate stages of treatment, using LC chromatographic equipped with MS detector with limit of quantification (LOQ) $0.005 \mathrm{ppb}$, measurement uncertainty (MU) 20 and recovery criteria from $85 \%$ to $130 \%$.Sample was 
collected from field in glass container and drinking water sample preserved by adding sodium thiosulfate to stop the reaction of chlorine. Raw water sample is filtered by membrane filter $(0.22 \mu \mathrm{m})$, and $20 \mu 1$ aliquot is injected (direct injection) into a reverse phase UPLC column C8 $(1.7 \mu \mathrm{m} * 2.1 * 50 \mathrm{~mm})$. Separation of the analytes is achieved using gradient eluent conditions with a mixture of (A) water and (B) methanol HPLC grade. Start by $90 \%$ (A) in the first $2.5 \mathrm{~min}$. to $10 \%$ (A) from 2.5 to $7.75 \mathrm{~min}$. then to $100 \%$ (B) from 7.75 to 8.50 min. then back to $90 \%$ (A) from 8.5 to 10 min., the flow rate was 0.450 $\mathrm{ml} / \mathrm{min}$. After elution from the UPLC column, the analytes were detected by a MS/MS detector (Xevo TQ-S) using Electron-Spray-ionization (ESI) in positive mode with the following conditions

Capillary volt=3.2 KV dessolvation temp. $=450 \mathrm{C}^{0}$

Desolvation $=800 \mathrm{~L} \backslash \mathrm{Hr}$ cone $=150 \mathrm{~L} \backslash \mathrm{Hr}$

Nebulizer $=7 \mathrm{bar}$

Each batch (20 samples) controlled by calibration curve consist of 7 points from $0.005 \mathrm{ppb}$ to $1.00 \mathrm{ppb}$. The calibration curve was checked by Lab control sample (LCS) at concentration $0.2 \mathrm{ppb}$. Also the batch was checked by organic free water (blank sample) which its result must be less than LOQ. 


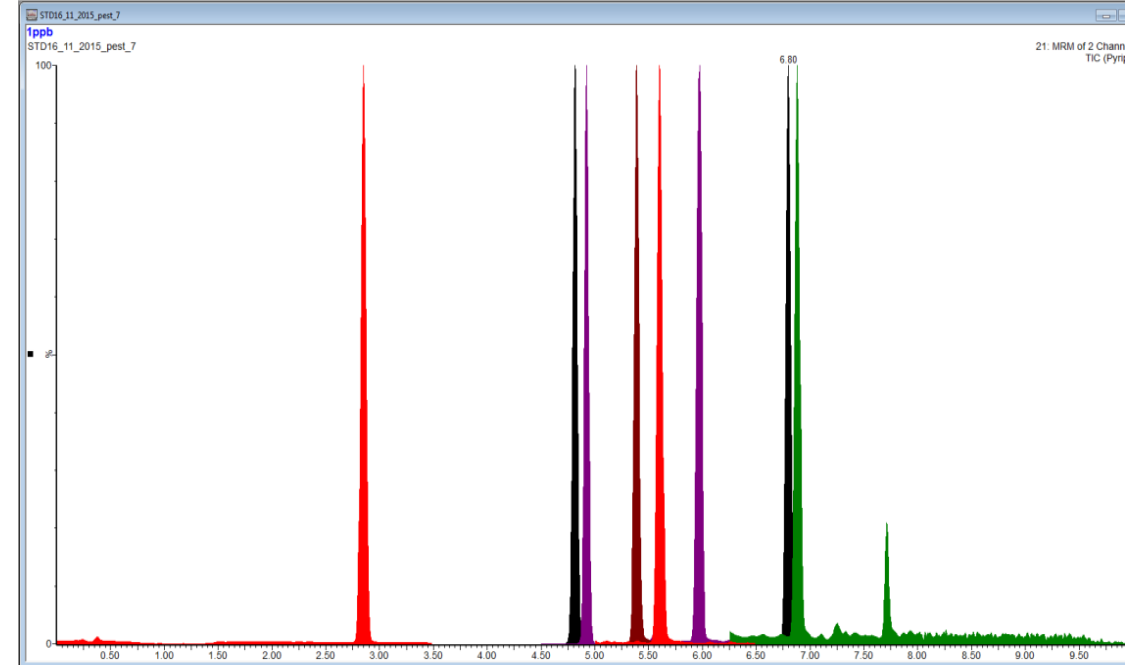

Figure (2): show pesticides compounds at concentration 1ppb

\section{2 removal of Atrazine by different treatment methods}

Removal of pesticides was performed using oxidation technique by Fenton oxidation and adsorption technique by (GAC)

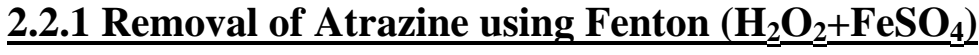

Effect of $\mathbf{H}_{2} \mathrm{O}_{2}$ : Each sample $(1000 \mathrm{ml})$ was spiked by atrazine compound at concentration $2 \mathrm{ppb}$ followed by adding different dosages of $\mathrm{H}_{2} \mathrm{O}_{2}$ at concentrations $(0.1 \mathrm{M}, 0.2 \mathrm{M}, 0.4 \mathrm{M}$ and $0.8 \mathrm{M})$ at constant concentration of $\mathrm{FeSO}_{4}(0.89 \mathrm{mM})$ to study the effect of $\mathrm{H}_{2} \mathrm{O}_{2}$.

Effect of $\mathrm{FeSO}_{4}$ : Each sample $(1000 \mathrm{ml})$ was spiked by atrazine compound at concentration $2 \mathrm{ppb}$ followed by adding different dosages of $\mathrm{FeSO}_{4}(0.05$ $\mathrm{mM}, \quad 0.1 \mathrm{mM}, \quad 0.22 \mathrm{mM}, 0.44 \mathrm{mM}, \quad 0.89 \mathrm{mM}$ and $1 \mathrm{mM})$ at constant concentration of $\mathrm{H}_{2} \mathrm{O}_{2}(0.4 \mathrm{M})$ to study the effect of $\mathrm{FeSO}_{4}$. 
Effect of pH: Each sample $(1000 \mathrm{ml})$ was spiked by atrazine compound at concentration $2 \mathrm{ppb}$ followed by adding constant dosages of $\mathrm{H}_{2} \mathrm{O}_{2}$ and $\mathrm{FeSO}_{4}$ at different $\mathrm{pH}$ conditions $(3,5,7,9$ and 11) to study the effect of $\mathrm{pH}$

Effect of time: After sample treated by Fenton $1.00 \mathrm{ml}$ of treated sample was taken at interval time (15min., 30min., 60min., and 120min.) to study the effect of time.

\subsubsection{Removal of Atrazine using (GAC):}

Effect of GAC amounts: Each sample $(1000 \mathrm{ml})$ was spiked by atrazine standard at concentration $2 \mathrm{ppb}$ followed by adding different amount of GAC $(0.1 \mathrm{~g}, 0.25 \mathrm{~g}, 0.5 \mathrm{~g}, 1 \mathrm{~g}$ and $2 \mathrm{~g})$ to study the effect of GAC amount.

Effect of pH: Each sample $(1000 \mathrm{ml})$ was spiked by atrazine standard at concentration $2 \mathrm{ppb}$ followed by adding constant amount of GAC (1g) at different $\mathrm{pH}$ conditions $(3,7$ and 11$)$ to study the effect $\mathrm{pH}$ condition.

Effect of time: For each sample was treated by Charcoal $1.00 \mathrm{ml}$ of treated sample was taken at interval of time (15min., 30min., 60min., and $120 \mathrm{~min}$.) to study the effect of time

\section{RESULTS AND DISSCUTIONS}

\section{Monitoring of Atrazine in different water plants at K. El Sheikh:}

In the field study a survey was performed on the different 18 water treatment plants in Kafr El Sheikh Governorate. 


\section{Monitoring of atrazine in kafr EI Sheikh:}

Table (1): Seasonal Monitoring of Atrazine in raw and Drinking water of water treatment plants at Kafr El Sheikh Gov ernorate during 2014.

\begin{tabular}{||l|c|c|l|c|c||}
\hline \multicolumn{1}{|c|}{$\begin{array}{c}\text { Kafr El Sheikh } \\
\text { Governorates } \\
\text { regions }\end{array}$} & summer & Spring & $\begin{array}{c}\text { Kafr El Sheikh } \\
\text { Governorates regions }\end{array}$ & summer & spring \\
\hline \hline K.El Sheikh(1) Tap & 0.052 & 0.017 & Abo Ali Tap & 0.028 & 0.009 \\
\hline K.El Sheikh(2) Tap & 0.059 & 0.005 & Abo Ali Intake & 0.049 & 0.008 \\
\hline K.El Sheikh(2)Intake & 0.037 & 0.017 & El hamol Tap & 0.082 & 0.009 \\
\hline Masser Tap & 0.037 & 0.009 & El hamol Intake & $0.131^{*}$ & 0.015 \\
\hline Masser Intake & 0.045 & 0.008 & Baltem Tap & 0.057 & 0.007 \\
\hline Qulene Tap & 0.024 & 0.023 & Baltem Intake & 0.038 & 0.008 \\
\hline Qulene Intake & 0.023 & 0.007 & El Riade Tap & 0.086 & 0.024 \\
\hline Abo Arafa Tap & 0.028 & 0.007 & El Riade Intake & $0.145^{*}$ & 0.048 \\
\hline Abo Arafa Intake & 0.109 & 0.030 & Mahlet Mousa Tap & 0.020 & 0.016 \\
\hline Haddadi Tap & 0.047 & --- & Mahlet Mousa Intake & 0.025 & 0.017 \\
\hline Haddadi Intake & 0.076 & --- & Newaga Tap & $0.141^{*}$ & 0.014 \\
\hline Qozo Tap & 0.095 & 0.008 & Newaga Intake & $0.127^{*}$ & 0.016 \\
\hline Qozo Intake & 0.089 & 0.009 & Ebishan Tap & 0.067 & --- \\
\hline Diai Tap & 0.032 & 0.008 & Ebishan Intake & $0.127^{*}$ & 0.016 \\
\hline Diai Intake & 0.057 & 0.010 & Greda Tap & 0.079 & 0.010 \\
\hline El Mandora Tap & $0.125^{*}$ & 0.007 & Greda Intake & 0.076 & 0.009 \\
\hline El Mandora Intake & $0.12^{*}$ & 0.008 & Fouh Tap & $0.147^{*}$ & ----- \\
\hline Shebas ElMahel Tap & $0.113^{*}$ & 0.008 & Fouh Intake & 0.150 & ----- \\
\hline $\begin{array}{l}\text { Shebas ElMahel } \\
\text { Intake }\end{array}$ & $0.115^{*}$ & 0.014 & & & \\
\hline \hline
\end{tabular}

$$
=\leq \mathrm{LOQ}=0.005 \mathrm{ppb}
$$

$(*)=$ results don't comply with the European and National drinking water quality standards $(0.1 \mu \mathrm{g} / \mathrm{l})$ 
J. Environ. Sci.

Institute of Environmental Studies and Research - AinShamsUniversity

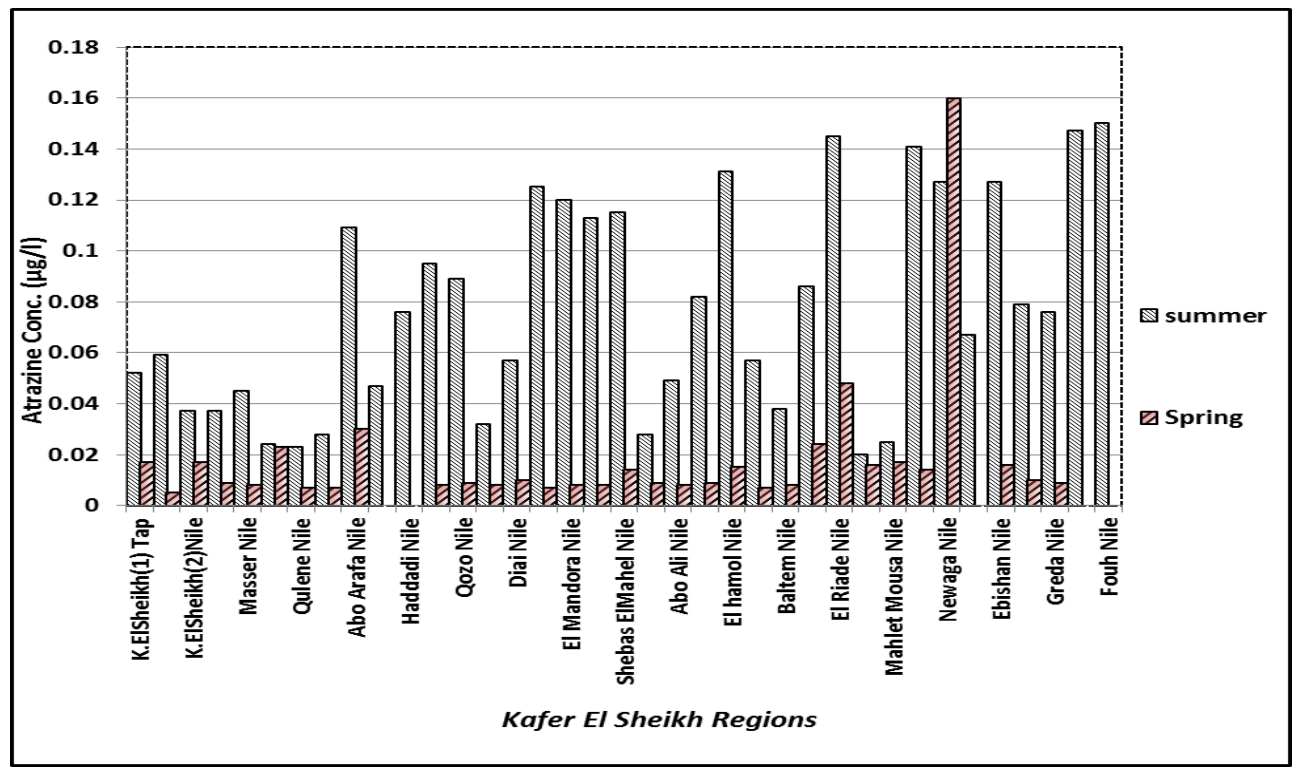

Figure (3): Monitoring of Atrazine in eighteen water treatment plants and their Nile in Kafr El Sheikh during four seasons of 2014.

Figure (3) showed that, the highest Atrazine concentration $(0.15 \mu \mathrm{g} / \mathrm{l})$ was found in the intake of Fouh Water treatment plant during summer due to the use of it as herbicides in corn and rice crops, otherwise atrazine disappeared during winter and autumn in all studied water treatment plants except Haddadi region, it was detected at $(0.006 \mu \mathrm{g} / \mathrm{l})$. Rodriguez et al., 2004; also reported the presence of atrazine at concentration of $0.463 \mu \mathrm{g} / \mathrm{l}$ in Llobregat River during June. The levels of triazines found in the Llobregat River were of the same order as those reported by other authors in southern European rivers. In northern European countries, triazines are found in surface waters at lower levels, from 0.01 to $0.1 \mu \mathrm{g} / \mathrm{l}$ (Van der Burggen et al., 2003). Also a study on atrazine monitoring in Slovenia from 1993 to 1996 showed that Atrazine concentrations were up to $7.23 \mu \mathrm{g} / \mathrm{L}$, and then they 62 
started to decrease to $0.06 \mu \mathrm{g} / \mathrm{l}$ (Pintar and Lobnik, 2001). Haldik et al., 2008, reported the presence of atrazine in Missouri River, Mississippi River and Vermillion River at median concentrations $0.78 \mu \mathrm{g} / \mathrm{l}$. So, from the represented data in Figure (3) all water treatment plants results for atrazine were under the most permissible level for WHO and Egyptian Minister of health regulations (2ppb). On the other hand, some regions like El Mandora, Shebas El Mahel, El Hamol, Elriad, Newaga , Ebishan and Fouh not comply with the European and National drinking water quality standards $(0.1 \mu \mathrm{g} / \mathrm{l})$. From Figure (3), the conventional treatment process in water treatment plants has no effect in atrazine removal which agrees with Jiang and Adams, (2006).

\section{Removal of Atrazine by different treatment techniques:}

\section{Fenton oxidation:}

Effect of $\mathrm{H}_{2} \mathrm{O}_{2}$ : As shown in Figure(4), at concentration of $0.1 \mathrm{M} \mathrm{H}_{2} \mathrm{O}_{2}$ about $83.4 \%$ of atrazine was removed after 2 hours and at $0.8 \mathrm{M} \mathrm{H}_{2} \mathrm{O}_{2}$ concentration, the extent of atrazine removal increases to $99.3 \%$ within 1 hour so that as the concentration of $\mathrm{H}_{2} \mathrm{O}_{2}$ increases the atrazine removal from water increases. (Wang et al., 2008) reported that increased $\mathrm{H}_{2} \mathrm{O}_{2}$ concentration accelerated the rate of dye degradation and (Benatti et al., 2006) reported an overall COD reduction of $92 \%$ at the optimal conditions of $\mathrm{H}_{2} \mathrm{O}_{2}$ : COD $=9: 1, \mathrm{Fe}^{2+}: \mathrm{H}_{2} \mathrm{O}_{2}=$ 1:4.5. The reaction rate constants were determined by simplifying the order of the reaction as pseudo first-order and by plotting $-\ln \left(\mathrm{C} / \mathrm{C}_{0}\right)$ versus time $(\mathrm{t})$ Figure (5), the highest $\mathrm{R}^{2}$ is (0.979) at concentration $0.2 \mathrm{M}$ of $\mathrm{H}_{2} \mathrm{O}_{2}$ and it clearly demonstrated that the rate of Atrazine removal increased proportionally with increasing $\mathrm{H}_{2} \mathrm{O}_{2}$ concentration, and that the linear 
relationship was not valid after $0.4 \mathrm{M}$. This can be explained by the scavenging of $\mathrm{OH}^{-}$by excess of $\mathrm{H}_{2} \mathrm{O}_{2}$ as suggested by ( Gogate and Pandit 2004). By plotting the $k^{\prime}$ against the concentration of $\mathrm{H}_{2} \mathrm{O}_{2}$ show that; as the concentration of $\mathrm{H}_{2} \mathrm{O}_{2}$ increases the rate constant increases due to increasing the amount of $\mathrm{OH}^{-}$so that the suitable point for atrazine removal is $(0.8 \mathrm{M})$ of $\mathrm{H}_{2} \mathrm{O}_{2}$. Also (Muruganandham and Swaminathan, 2004) reported that in small concentrations, increase of the amount of peroxide causes an increase of the reaction rate since more hydroxyl radicals are produced.

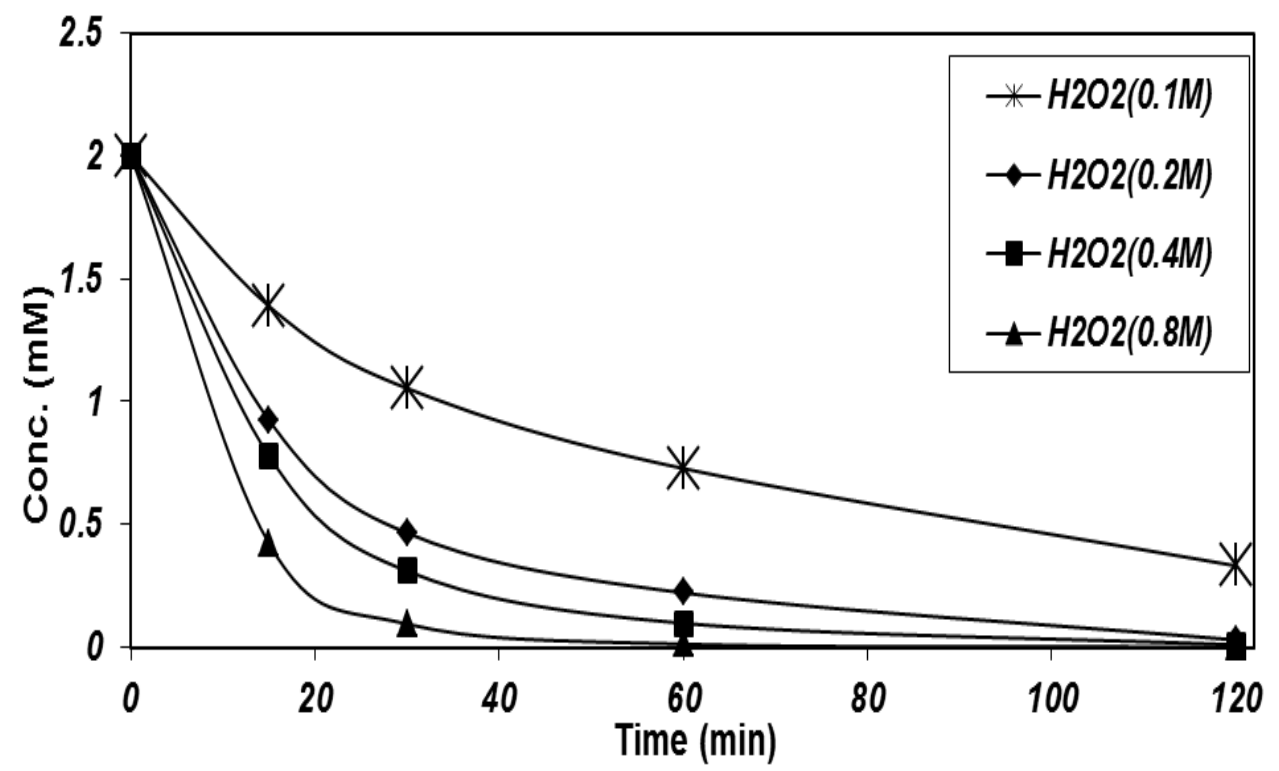

Figure (4): Atrazine removal by various concentrations of $\mathrm{H}_{2} \mathrm{O}_{2}$ at $0.89 \mathrm{mM}$ of $\mathrm{FeSO}_{4}$. Atrazine concentration at zero time was $2.0 \mathrm{ppb}$ ). 


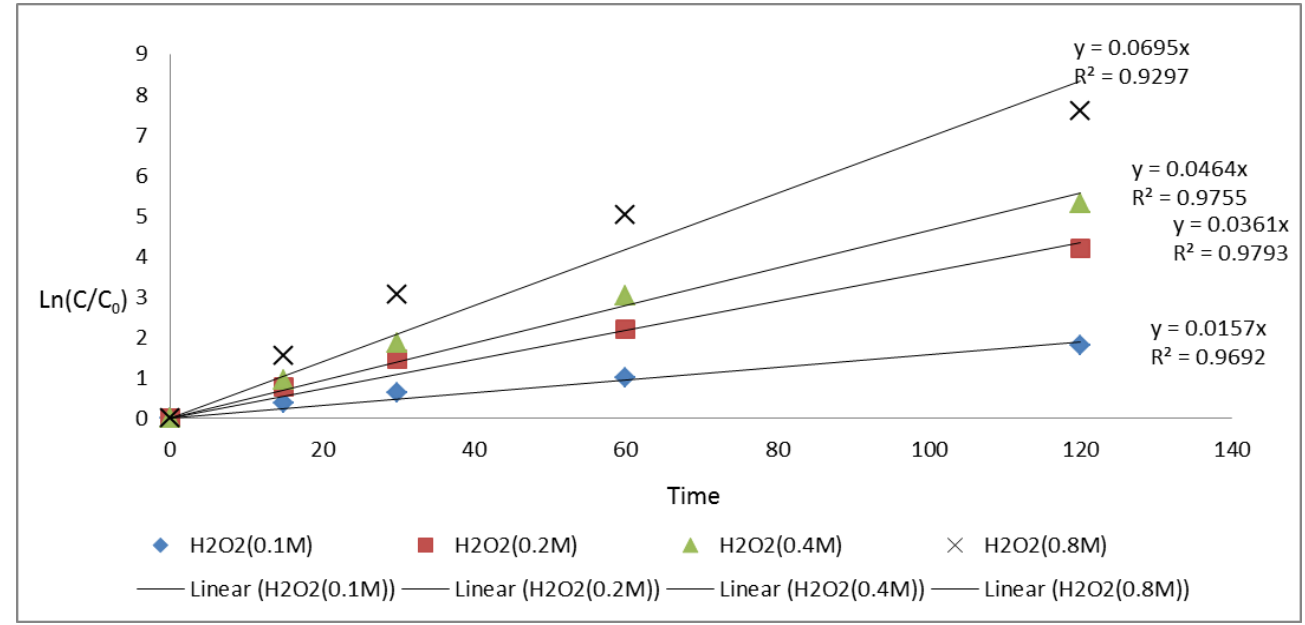

Figure (5): The relation between $\operatorname{Ln}\left(\mathrm{C} / \mathrm{C}_{0}\right)$ and contact time

Effect of $\mathrm{FeSO}_{4}$ : As shown in Figure (6). At concentration of $0.05 \mathrm{mM} \mathrm{FeSO}_{4}$ no significant removal of atrazine observed, at concentration $0.1 \mathrm{mM} \mathrm{FeSO}_{4}$ only about $46.6 \%$ of atrazine was removed after 2 hours and at concentration of $0.89 \mathrm{mM} \mathrm{FeSO}_{4}$ the extent of atrazine removal increases to 99.5 within lhour. This result confirmed by (Wang et al., 2008) who found that increasing $\mathrm{FeSO}_{4}$ dosages, the rate of dye degradation is accelerated and (Gulkaya et al., 2006) They found that the optimal molar ratio of $\mathrm{H}_{2} \mathrm{O}_{2} / \mathrm{Fe}^{+2}$ fell within the range of 1:153 to 1:470 which achieved 90-95\% COD removal. The reaction rate constants were determined by simplifying the order of the reaction as pseudo first-order and by plotting $-\ln \left(\mathrm{C} / \mathrm{C}_{0}\right)$ versus time $(\mathrm{t})$, Figure (7). The best $\mathrm{R}^{2}$ is (0.997) at concentration $0.89 \mathrm{mM}$ of $\mathrm{FeSO}_{4}$, and By plotting the $k^{\prime}$ against the concentration of $\mathrm{FeSO}_{4}$ this clearly demonstrated that as concentration of $\mathrm{Fe}^{+2}$ increases the rate constant increases due to increasing the amount of catalysts until concentration $1 \mathrm{mM}$ 
the rate constant decrease. This may be explained by redox reaction that $\mathrm{OH}^{*}$ (hydroxyl radical) is scavenged either by the reaction with hydrogen peroxide or by the reaction with $\mathrm{Fe}^{+2}$, as expressed in the equations (Malik and Saha, 2003).

$$
\begin{array}{lll}
\mathrm{H}_{2} \mathrm{O}_{2}+\mathrm{OH}^{*} & \rightarrow & \mathrm{H}_{2} \mathrm{O}+\mathrm{OH}_{2}^{*} \\
\mathrm{Fe}^{+2}+\mathrm{OH}^{*} & \rightarrow & \mathrm{OH}^{-}+\mathrm{Fe}^{+3}
\end{array}
$$

It is obvious that the increase of iron concentration causes an increase in the reaction rate. As already mentioned, ferric ions are photo reduced to ferrous ions. The latter are the main species that can catalyze hydrogen peroxide to produce hydroxyl radicals. As a result, the amount of ferric ions added is directly proportional to the hydroxyl radicals produced and consequently to the photo catalytic degradation rate of the insecticides (Muruganandham and Swaminathan, 2004). So the suitable concentration for atrazine removal was $(0.89 \mathrm{mM})$ of $\mathrm{FeSO}_{4}$ 


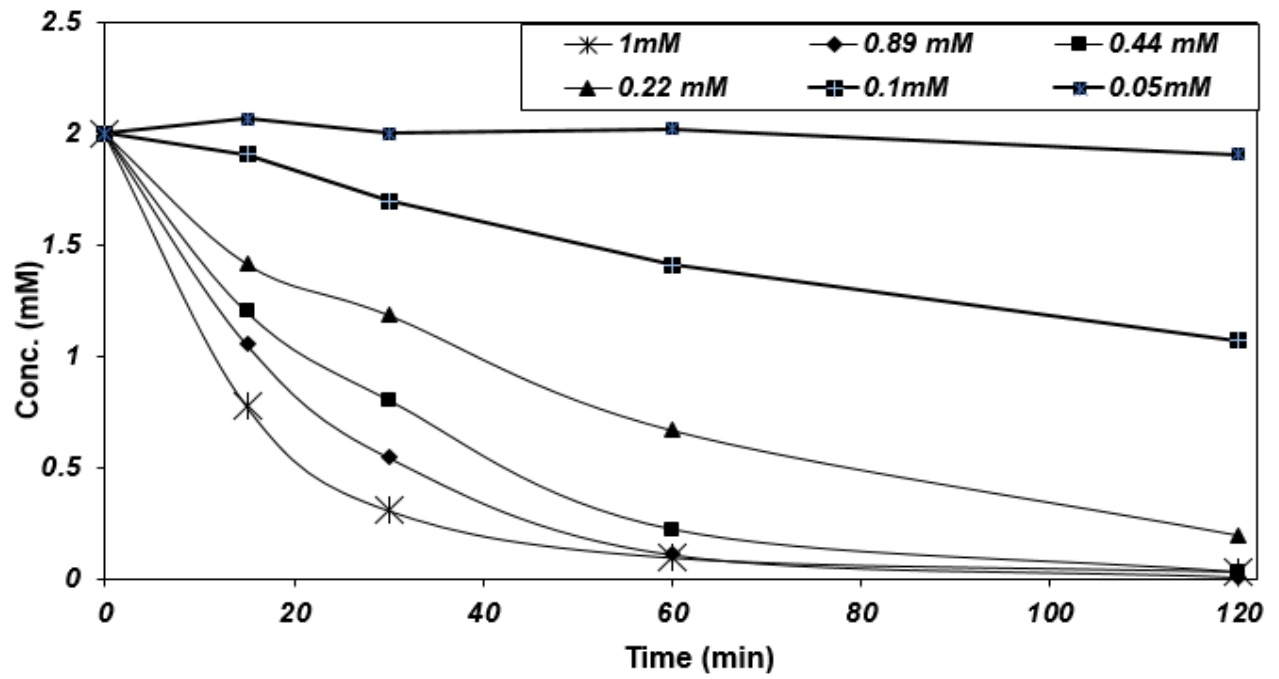

Figure (6): Atrazine removal by various concentrations of $\mathrm{FeSO}_{4}$ at $0.4 \mathrm{M}$ of $\mathrm{H}_{2} \mathrm{O}_{2}$. (Atrazine concentration at zero time was $2.0 \mathrm{ppb}$ )

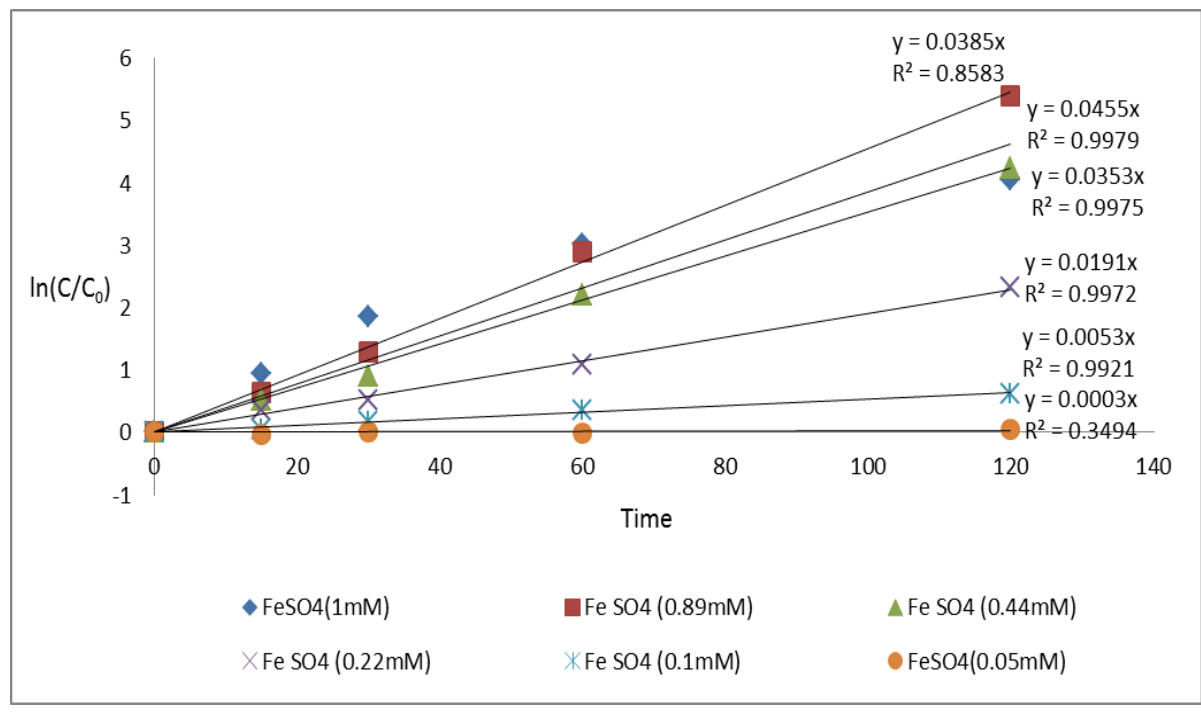

Figure (7): The relation between $\operatorname{Ln}\left(\mathrm{C} / \mathrm{C}_{0}\right)$ and contact time 
Effect of pH: Fenton oxidation of atrazine was studied over $\mathrm{pH}$ range from pH 3 to pH 11 as shown in Table (2)

Table (2): Effect of $\mathrm{pH}$ on atrazine removal

\begin{tabular}{|l|l|l|l|l|l|}
\hline Factors & pH3 & pH5 & pH7 & pH9 & pH11 \\
\hline R $^{2}$ & 0.977 & 0.974 & -3.79 & -0.487 & -2.82 \\
\hline k & 0.053 & 0.044 & 0.033 & 0.026 & 0.014 \\
\hline
\end{tabular}

As shown in table (2) the reaction rate constants were determined by simplifying the order of the reaction as pseudo first-order and by plotting $\ln \left(\mathrm{C} / \mathrm{C}_{0}\right)$ versus time $(\mathrm{t})$ the highest $\mathrm{K}$ constant and $\mathrm{R}^{2}$ were at $\mathrm{pH} 3$ so that the suitable $\mathrm{pH}$ condition for atrazine removal was at $\mathrm{pH} 3$. $\mathrm{pH}$ plays a crucial role in photo Fenton reaction effi ciency, because it strongly infl uences which complexes are formed. Thus, $\mathrm{pH} 2.8$ has frequently been postulated as an optimum $\mathrm{pH}$ for photo-Fenton treatment, because at this $\mathrm{pH}$ there is no precipitation yet and the predominant iron species in the solution is $[\mathrm{Fe}(\mathrm{OH})]$ ${ }^{2+}$, the most photoactive ferric iron-water complex (Pignatello et al., 2000). Also these results are in agreement with related studies of other researchers like (Wang et al., 2008 ) reported that decrease in $\mathrm{pH}$ from 6.3 to 2.4 or 3.4 significantly improved the rate of dye degradation, (Gogate and Pandit 2004) reported that the optimum $\mathrm{pH}$ condition was found to be $3-4$, and the highest oxidation efficiency was reported when acetic acid/acetate buffer was used instead of phosphate and sulphate buffers which encouraged the formation of stable $\mathrm{Fe}^{3+}$ complexes and (Bautista et al., 2007) was found highest removal of total organic carbon (TOC) at $\mathrm{pH} 2.5-3$. 


\section{Granulat47323+995547/*-ed Activated Carbon Adsorption(GAC):}

As shown in Figure(8) at $0.1 \mathrm{~g}$ of GAC $37.7 \%$ of Atrazine was removed after 2 hours contact time, at $0.25 \mathrm{~g}$ of GAC $62.3 \%$ of Atrazine was removed after 2 hours contact time and at $2 \mathrm{~g}$ of GAC the extent of atrazine was removed after 2 hours contact time. This result confirmed by (Amy et al., 2012) reported that $92 \%$ removal was achieved with a mass ratio of activated carbon to atrazine of 18:1. Also (Sarkar et al., 2006) was found that Activated carbon highly effective for removal toxic pesticides organic compound. The reaction rate constants were determined by simplifying the order of the reaction as pseudo first-order and by plotting $-\ln \left(\mathrm{C} / \mathrm{C}_{0}\right)$ versus time $(\mathrm{t})$ Figure (9). The best $\mathrm{R}^{2}$ is 0.973 at amount $0.25 \mathrm{~g}$ of GAC and the linear relation was not valid as the amount of GAC decreases beyond $0.5 \mathrm{~g}$. By plotting $\mathrm{k}$ versus the amount of charcoal, as the amount of charcoal increases the rate constant increases so that the suitable amount for atrazine removal is $2 \mathrm{~g}$ of GAC. This result was agreement with related study (Gupta et al., 2011) concluded that pseudo first order reaction adsorption model is suitable for pesticides adsorption and (Hameed et al., 2009) reported that pseudo first order reaction adsorption model is suitable for 2,4D pesticide adsorption on activated carbon. 
J. Environ. Sci.

Institute of Environmental Studies and Research - AinShamsUniversity

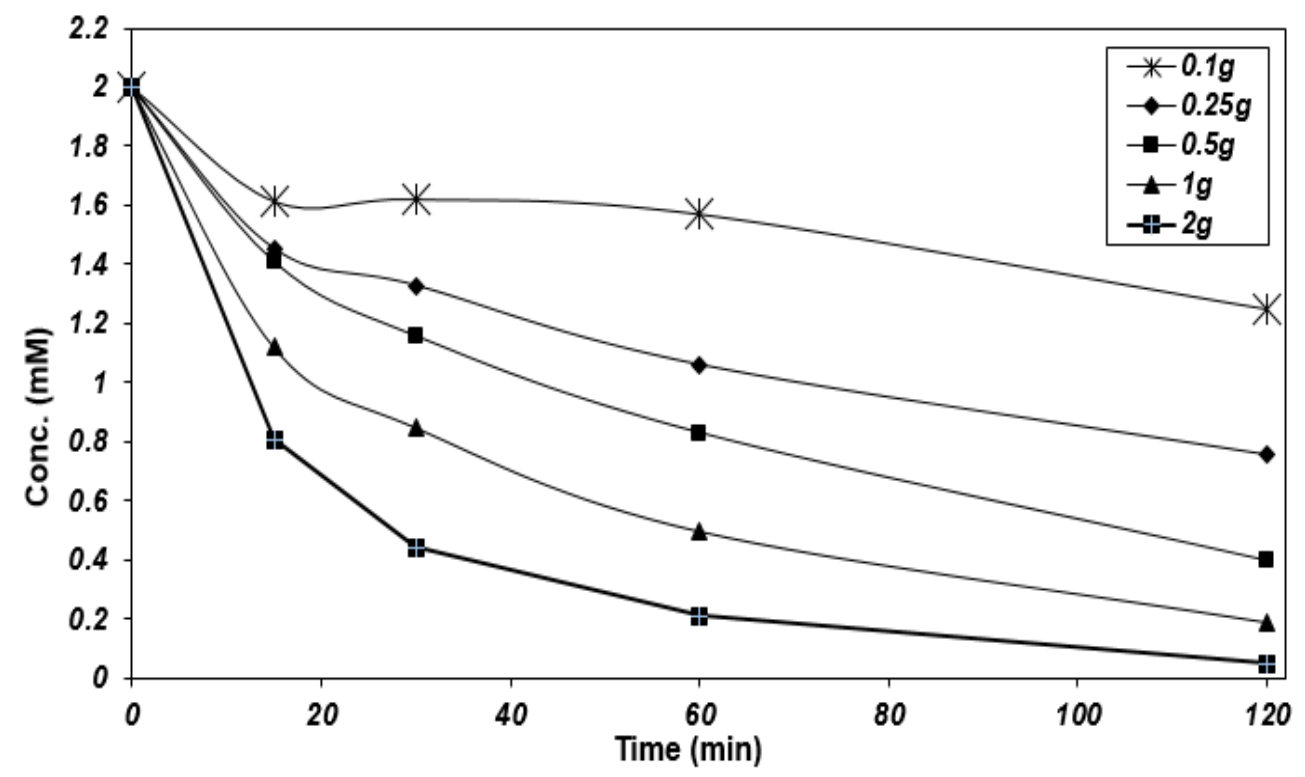

Figure (8): Atrazine removal by various Amounts of GAC. Atrazine concentration at zero time was $2.0 \mathrm{ppb}$

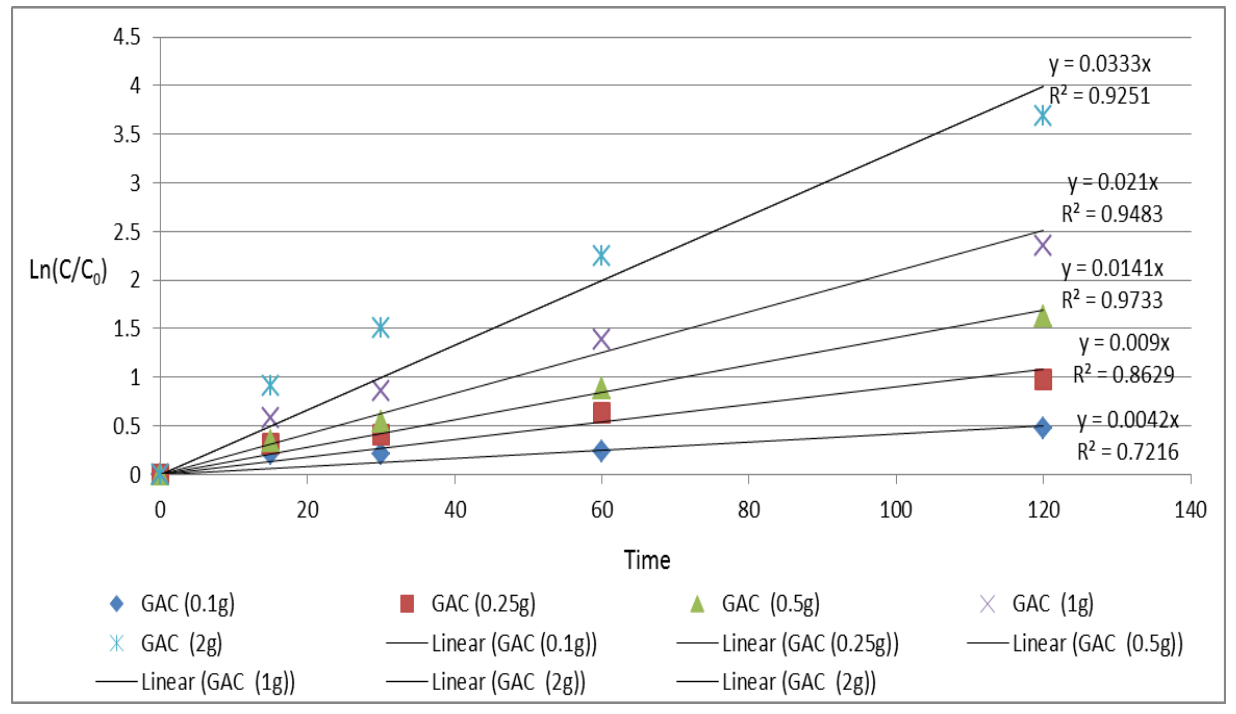

Figure (9): The relation between $\operatorname{Ln}\left(\mathrm{C} / \mathrm{C}_{0}\right)$ and contact time 
Effect of pH: The adsorption of the atrazine was studied at pH3, 7and 11 the result plotted in Figure (10) showed that

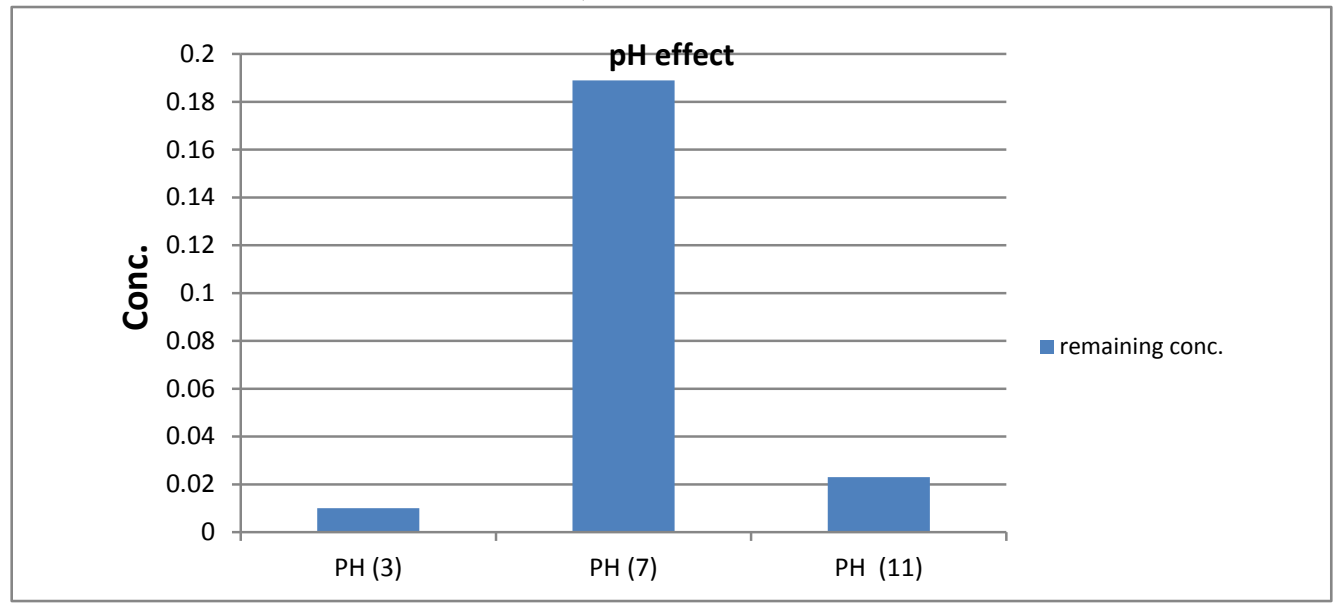

Figure (10): The effect of $\mathrm{pH}$ on atrazine removal

the adsorption capacity of atrazine was greater at $\mathrm{pH} 3$ this due to deprotonation increases with increases in $\mathrm{pH}$, this deprotonation results in a more negative charged carbon surface at higher $\mathrm{pH}$ than at lower $\mathrm{pH}$ values. The negative charge developed at carbon surface due to deprotonation cause strong electrostatic repulsion for pesticides in solution while with decreases in $\mathrm{pH}$ value, deprotonation decreases (Gupta and Ali, 2006).

\section{CONCLUSIONS}

Samples were collected from eighteen water treatment plants in K.El Sheikh Governorate during one year (2014). The study recorded the presence of atrazine at concentration $0.1 \mathrm{ppb}$ and the conventional treatment process effectiveless on atrazine treatment. This study demonstrated the possibility of realizing a quasi-complete removal of atrazine in aqueous solution by means 
of the photo-Fenton process and GAC. The degradation rate by photoFenton process was found to depend on the $\mathrm{H}_{2} \mathrm{O}_{2}$ and $\mathrm{Fe}^{3+}$ initial concentrations as well as $\mathrm{pH}$ and contact time, the highest degradation value (99\%) was obtained after one hour of treatment. The adsorption of atrazine by GAC was found to depend on the amount of GAC, $\mathrm{pH}$ and contact time, the highest adsorption value (97\%) was obtained after 2 hours contact time.

\section{REFERENCE}

Amy B., Erik K., Joshua P. (2012): Pesticide Removal from Water, Master's Thesis, Worcester Polytechnic Institute (WPI), Worcester, Massachusetts.

Bautista, P., Mohedano, A. F., Gilarranz, M. A., Casas, J. A., \& Rodriguez, J. J. (2007): Application of Fenton oxidation to cosmetic wastewaters treatment. Journal of Hazardous Materials, 143(1), $128-134$

Benatti, C. T., Tavares, C. R. G., \& Guedes, T. A. (2006): Optimization of Fenton's oxidation of chemical laboratory wastewaters using the response surface methodology. Journal of Environmental Management, 80(1), 66-74.

Chan, K. H., \& Chu, W. (2003): Modeling the reaction kinetics of Fenton's process on the removal of atrazine. Chemosphere, 51(4), 305-311.

Claver, A., Ormad, P., Rodríguez, L., \& Ovelleiro, J. L. (2006): Study of the presence of pesticides in surface waters in the Ebro river basin (Spain). Chemosphere, 64(9), 1437-1443.

EPA 536, Determination of triazine Pesticides and their degradation in drinking water by liquid chromatography electron spray inonization tandem mass spectrometry (LC/ESI/MS/MS), version $1.0,2007$ 
El Sebaï, T., Devers-Lamrani, M., Changey, F., Rouard, N., \& MartinLaurent, F. (2011): Evidence of atrazine mineralization in a soil from the Nile Delta: isolation of Arthrobacter sp. TES6, an atrazine-degrading strain. International Biodeterioration \& Biodegradation, 65(8), 1249-1255.

Gogate, P. R., \& Pandit, A. B. (2005): A review of imperative technologies for wastewater treatment II: hybrid methods. Advances in Environmental Research, 8(3), 553-597

Guan, Y. H., Ma, J., Ren, Y. M., Liu, Y. L., Xiao, J. Y., Lin, L. Q., \& Zhang, C. (2013): Efficient degradation of atrazine by magnetic porous copper ferrite catalyzed peroxymonosulfate oxidation via the formation of hydroxyl and sulfate radicals. Water research, 47(14), 5431-5438.

Gulkaya, I., Surucu, G. A., \& Dilek, F. B. (2006): Importance of H2 O 2/Fe $2+$ ratio in Fenton's treatment of a carpet dyeing wastewater. Journal of Hazardous Materials, 136(3), 763-769.

Gupta, V. K., \& Ali, I. (2008): Removal of endosulfan and methoxychlor from water on carbon slurry. Environmental science \& technology, 42(3), 766-770.

Gupta, V. K., Gupta, B., Rastogi, A., Agarwal, S., \& Nayak, A. (2011): Pesticides removal from waste water by activated carbon prepared from waste rubber tire. Water research, 45(13), 4047-4055.

Hamdaoui, O., Naffrechoux, E., Suptil, J., \& Fachinger, C. (2005): Ultrasonic desorption of p-chlorophenol from granular activated carbon. Chemical Engineering Journal, 106(2), 153-161.

Hameed, B. H., Salman, J. M., \& Ahmad, A. L. (2009): Adsorption isotherm and kinetic modeling of 2, 4-D pesticide on activated carbon derived from date stones. Journal of Hazardous Materials, 163(1), 121-126.

Hladik, M. L., Bouwer, E. J., \& Roberts, A. L. (2008): Neutral degradates of chloroacetamide herbicides: Occurrence in drinking water and 
removal during conventional water treatment. Water research, 42(20), 4905-4914.

Jiang, H., \& Adams, C. (2006): Treatability of chloro-s-triazines by conventional drinking water treatment technologies. Water research, 40(8), 1657-1667

Legube, B., Parinet, B., Gelinet, K., Berne, F., \& Croue, J. P. (2004): Modeling of bromate formation by ozonation of surface waters in drinking water treatment. Water research, 38(8), 2185-2195.

Malik, P. K., \& Saha, S. K. (2003): Oxidation of direct dyes with hydrogen peroxide using ferrous ion as catalyst. Separation and purification technology, 31(3), 241-250.

Marchetti, G., Minella, M., Maurino, V., Minero, C., \& Vione, D. (2013): Photochemical transformation of atrazine and formation of photointermediates under conditions relevant to sunlit surface waters: Laboratory measures and modelling. Water research, 47(16), 6211-6222.

Muruganandham, M., \& Swaminathan, M. (2004): Decolourisation of Reactive Orange 4 by Fenton and photo-Fenton oxidation technology. Dyes and Pigments, 63(3), 315-321.

Pignatello, J. J., Oliveros, E., \& MacKay, A. (2006): Advanced oxidation processes for organic contaminant destruction based on the Fenton reaction and related chemistry. Critical reviews in environmental science and technology, 36(1), 1-84.

Pintar M. and Lobnik F. (2001): Dinamika pojavljanja pesticidov in nitratov v podtalnici pod intenzivnimi kmetijskimi povr\{inami, Zbornik: Zdravstvena ustreznost pitne vode in varnost oskrbe, , pp. 39-47

Ralebitso, T. K., Senior, E., \& Van Verseveld, H. W. (2002): Microbial aspects of atrazine degradation in natural environments. Biodegradation, 13(1), 11-19. 
Reid, D. C., Edwards, A. C., Cooper, D., Wilson, E., \& Mcgaw, B. A. (2003): The quality of drinking water from private water supplies in Aberdeenshire, UK. Water research, 37(2), 245-254.

Richards, R. P., Baker, D. B., Christensen, B. R., \& Tierney, D. P. (1995): Atrazine exposures through drinking water: Exposure assessments for Ohio, Illinois, and Iowa. Environmental science \& technology, 29(2), 406-412.

Rodriguez-Mozaz, S., de Alda, M. J. L., \& Barceló, D. (2004): Monitoring of estrogens, pesticides and bisphenol $\mathrm{A}$ in natural waters and drinking water treatment plants by solid-phase extraction-liquid chromatography-mass spectrometry. Journal of Chromatography A, 1045(1), 85-92.

Sarkar, B., Venkateswralu, N., Rao, R. N., Bhattacharjee, C., \& Kale, V. (2007): Treatment of pesticide contaminated surface water for production of potable water by a coagulation-adsorptionnanofiltration approach. Desalination, 212(1), 129-140.

Thurman, E. M., Meyer, M. T., Mills, M. S., Zimmerman, L. R., Perry, C. A., \& Goolsby, D. A. (1994): Formation and transport of deethylatrazine and deisopropylatrazine in surface water. Environmental science \& technology, 28(13), 2267-2277.

Van der Bruggen, B., \& Vandecasteele, C. (2003): Removal of pollutants from surface water and groundwater by nanofiltration: overview of possible applications in the drinking water industry. Environmental pollution, 122(3), 435-445.

Wadley, s., and Waite, T.D. (2004): Fenton Processes. Advanced Oxidation for Water and waste water treatment, Vol. (4), 111-136

Wang, C. T., Hu, J. L., Chou, W. L., \& Kuo, Y. M. (2008): Removal of color from real dyeing wastewater by Electro-Fenton technology using a three-dimensional graphite cathode. Journal of Hazardous Materials, 152(2), 601-606. 


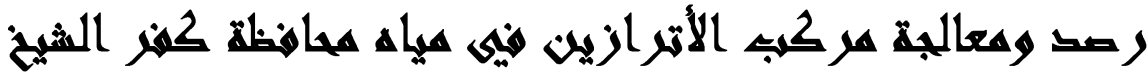

\section{[६]}

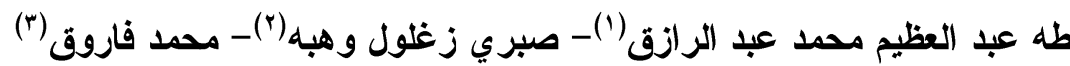

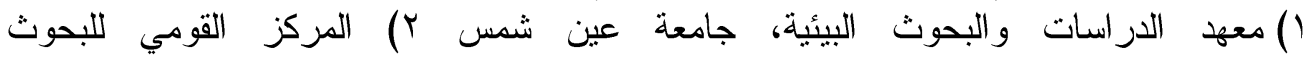
r) الثركه القابضه لمياه الثرب والبرث الصرف الصحي.

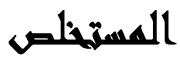

المبيدات لها تأثير سلبي علي البيئه وصحة الإنسان ولذلك قد تم تصنيفه كأحد المسبيات

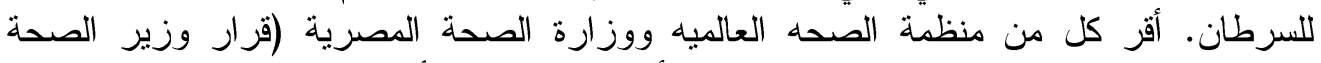

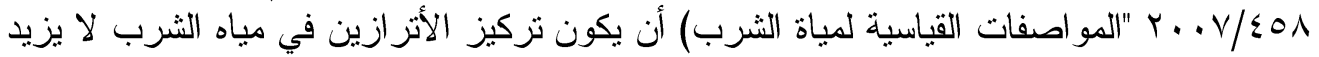

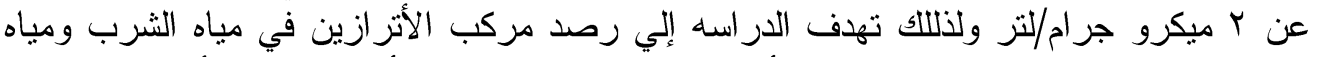

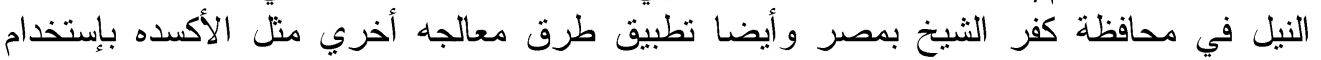

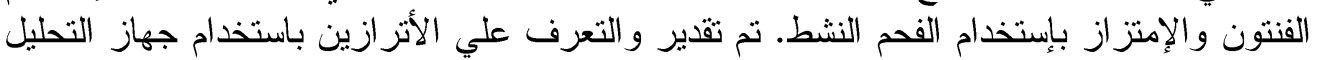

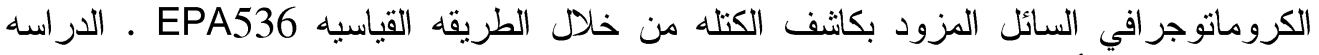

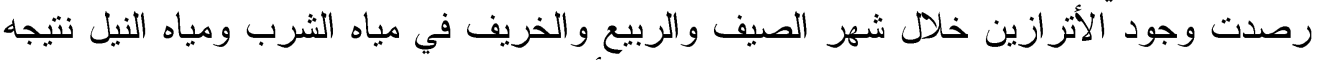

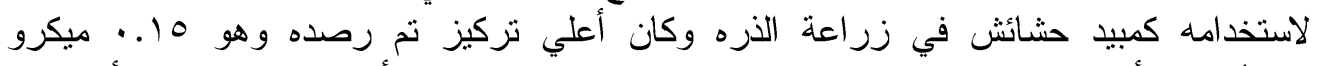

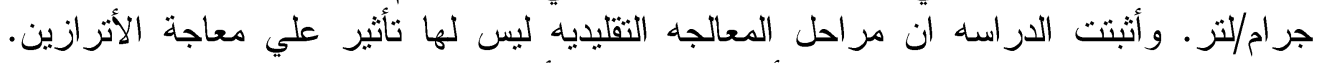

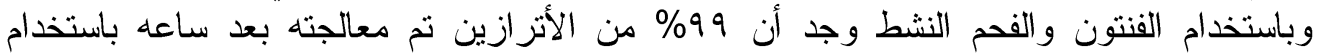
الفنتون و 9 \% و تم معالجته بعد ساعتين بإستخدام الفحم النشط. 